\title{
Funerals, Opposition and Protest between France and Brazil in nineteenth century
}

DOI

http://dx.doi.org/10.1590/2236-463320150904

\author{
Claudia Rodrigues \\ History Ph. D by Universidade \\ Federal Fluminense (UFF - Niterói- \\ RJ / Brasil). Associate Professor \\ of the Department and Program \\ of post-Graduation in History of \\ Universidade Federal do Estado do \\ Rio de Janeiro (UNIRIO - Rio de \\ Janeiro-RJ/Brazil) \\ e-mail: claudiarodrigues.3@ \\ hotmail.com
}

\begin{abstract}
This article seeks to establish some comparative points about the so-called "opposition funerals", in nineteenth-century in France and Brazil, from propositions presents in the innovative approach of Emmanuel Fureix proposals on the occasion of the Forum Magazine Almanack, occurred in 26/08/2014, which is shown here as article. In this work, Fureix analyzed the protest rites in France of the 1830s and 1840s and among them focused the funerals of Liberals that became ceremonial opposed to the government of the monarchist Restoration, giving new kinds of funeral rites. The dialogue with their proposals will seek to analyze the feasibility of reflecting on such opposition burials in nineteenth-century Brazil.
\end{abstract}

Keywords

opposition funerals, civil burial, funeral rites, protest 
The text of Emmanuel Fureix, Rites of protests and democratic tensions in France of the romantic age (1820-1848), presents a synthesis of aspects dealt by him in his book, La France des larmes, Deulis politques $\dot{a}$ I'âge romantique: 1817-1840 (which we can be translated as The France of tears: political mourning at the romantic age: 1847-1840), published in 2009, is the fruit of his Doctorate thesis. For the specific purpose of the article present at the forum of the magazine Almanack, Fureix inserted his analysis between the ways he identifies as a historiographic renovation of the last fifteen ears, what he called as "archeology of popular politicization and democratic experience". His purpose is perfectly placed at the range of the New Political History, particularly because it longs for a place next to the cultural history when it offers an anthropological review of the symbolisms, representations and the life experiences of the funeral rites taking in account the relationship between politics and power.

I understand the "public area of confrontation" as an unofficial public sphere, pointed outside the true institutions and expressing a voice of protest which would be made more of singular experience than abstract generalizations, the author offers to study what he names rites of protests including as models the opposition burials, charivaris and feasts. According to him, these actions bear witness to the seizure of word in a public space rearranged by the crisis of the Empire and by the institution of a representative based monarchy. Out of the space destined to the institutionalized known ways - as census voting, parliament resolutions, petitions, the media -, he claims that a public space would need to be developed in the gaps of the political representation. In that sense, he intends to analyze by what means it had been created a different political representation of the official scene, but in relation to it, what new and delicate ways of political involvement had been created, which he qualified as "pre-democratic" since the first half of the nineteenth century, between 1814 and 1848; in blunt, the period of the Bourbon Restoration and the July Monarchy, when happened the advent of a bourgeoisie royalty, with the predominance of the high bourgeoisie.

One of the favored rituals in his work - which I will focus in this text - is what we can translate as "manifestation-burials" or "opposition funerals". According to him, these would be funerals which translate the takeovers of the public space due to certain burials for purposes of political riots, which would be inventions of the Bourbon Restoration. Not knew during the Revolution and the Empire, they had been realized first by French students because a violent death of one of them, Nicolas Lallemand, killed by a royal guard (during a riot against a new restrictive electoral law) in June, 1820. His funeral was followed by more or less 6000 individuals to the public graveyard next to Pére-Lachaise (built in 1804), in Paris, silently crossing the city to make homage to what would be a martyr of freedom and defender of the constitutional letter threatened by the ultra-royalists.

According to Fureix, after this inaugural event, gradually in Paris, something like 33 funerals of individuals involved in the liberal and republican opposition would be public demonstrations of visibility, reorganizing thousands or dozens of thousands of people, between 1820 and 1830, during the burials of: Sébastien-Maximilien Foy, François-Joseph Talma, Jacques-Antoine Manuel and the Duke of La Rochefioucauld-Liancourt, during the Bourbon Restoration; and Benjamin Constant, the abbot 
The complementary references to the ones brought by me to the article were taken from his book. Cf. FUREIX, Emmanuel. La France des larmes. Deuils politiques à l'âge romantique (1814-1840). Paris: Champ Vallon, 2009. p.331.

2

Ibidem, p.342.
Baptiste-Henri Grégoire, Maximilien Lamarque, La Fayette and Armand Carrel, under the July Monarchy. The ritual would be politicized after a series of details that would discern it from a common rite of passage realized until then. In this type of ritual the quantity of present people would acquire a portray of "public opinion" and the motion of the crowd would be more significant than the monopolized in the public ceremonial space caused by official celebrations of sovereignty and religious procession.

These rituals would possess a primacy of profanity and, still being minority civilian, they eclipsed the religious aspect in stages of their development. The clergy would be total absent of the apotheosis of the funeral, either during the entry into the graveyard and even at the statement of the eulogies over the grave. Even during the rapprochement between the Church and the State, during the French Restoration, it would not be nonexistent the choice for more civilian funerals. In this mater, Fureix mentions the case of the performer Talma, who was at the verge of death, refused the last sacraments taken by the archbishop of Paris and had a funeral with highly demonstration of "atheism", which would remember the dechristianization of the revolutionary period amid 1793-941.

Some symbolic elements began to be introduced in these funeral rites, which the author called profanes: civilian crowns made of oak or undying, placed on the coffin, that reminded of the revolutionary ritual; the carry of the coffin in the arms or above the shoulders by students during part of or during the entire course of the ritual, contrary to the military ban (motion that, according to the author, behaved a strong and symbolic dimension to the extent that appeared as a representation/idealized delegation of the electorate at the figure of the dead) and aimed to break up with the pomp of the official burials with the abandoning the funeral car ${ }^{2}$. Different elements were included in the years following 1830, with the use of flags and banners (particularly of corporate source) with colors more or less subversive; the red cap and the red flag during the funeral of General Lamarque (who ultimately had helped to introduce this color in the scenery of the left-wing in the French Republic); other than confined silence and fallen tears, shouting and songs (some of them revolutionary) were mentioned at some point, inverting the funeral rite into a rite of life and, like that, leading to scandals; the making of speeches over the graves (some who were later published in the media or pamphlets) constituted the takeover of the political voice, evoking the past of the departed or a revolution transformed in a type of taboo, criticizing the official power or announcing better days under the sign of the progress.

These rites show us, according to the author, the strength of an informal and not violent politicization during the romantic age, who invented new forms of unprecedented democratic sense. They showed a nationalization of the politics still in embryonic form and an integration of included (the electorate and notable) and excluded (not voters, popular classes and young people). Manipulated by the liberals, these rites would end escaping them, by the time they were put in scene, through the symbolic power, the active people who would largely surpass the limits of the political repression as minded by the liberals, established over a rational and pool tax voting model, once they made possible the competition of a public opinion larger than the electorate of the liberal minority.

According to Fureix, the opposition funerals would have met acceleration between 1825 and 1827, in a moment which the liberals were weak 
3

Ibidem, p.368-372.

4

REIS, João José. A morte é uma festa: ritos fúnebres e revolta popular no Brasil no século XIX. São Paulo: Cia. das Letras, 1991. inside the Political Chamber and searched to openly claim their power in the society, showing that the oppositionist public sphere would not restrict to the parliamentary scene. One of the examples would be the establishment of subscription campaigns, who translated the emergent political nationalization. In the funerals case, these campaigns would translate as measures destined to provide funding to the construction of the grave for the deceased (as were made for the grave of General Foy, who raised more than one million of francs amid 1825-1826). In this matter, the space of the article made by Fureix destined to the funerals did not leave space for him to analyze - as he has done in his book ${ }^{3}$ - how these graves were made, like the symbolism of their architecture and the epitaph they contain, in order to identify by what means the constructions would express the conceptions he had highlighted in his article.

These opposition rites would raise some aspects related to the political sovereignty, questioning the limits of the political space officially set. The crowd present in them in the 1820's would exceed by far the category of the census voters: the students (who initiated the movement) were followed by shopkeepers, merchants, workers, who crossed the funerals against the elite to watch them as a type of entertainment. Compared to the banquets, the funerals would allow greater social divergence as it was not necessary to pay for the access. But the equality would be just apparent, as the environment of the ritual were occupied by the notables; once the rope and the canopy who covered the coffin were supported by the notables; once the speeches over the grave were made by Members of the Chamber. In the 1830's, would be far more participation and introduction of the masses, as workers, who helped to carry the coffin and transport the ropes and canopy. The opposition funerals would become, that way, a manner to conduct visibility and equality; mainly when some signs of social distinction would evoke rebukes and even when women and children were admitted.

Such protest rites would hence draw a singular moment of politicization in the pre-democratic French, answering by itself to an opening in the public space for deliberation and criticism even in the first half of nineteenth century. As Fureix argues, the modernization of the collective action repertory in the second half of the nineteenth century would not be possible without the transformation of the oppositionist public space of this first half of the 1800 .

This approach made by Emmanuel Fureix show us an exciting panel of thought about the emergence of new actions made upon facing death in the period immediately after the French Revolution. His contribution to the discussion about the transformation of the traditional funeral rites used in catholic societies is essential to the comprehension of the historicity of the rites of passage. In the Brazilian historiography about death - or even amid the scholars of politics during the Imperial period - there is still not a single line of specific studies about this type of "opposition burials" or even funeral protests for the first half of the nineteenth century as Fureix did.

In Brazil, the funerals during the first half of the 1800's were mainly marked by the power of the catholic tradition. As an example is the specific case of riot we have; the "cemiterada". Brilliantly studded by João José Reis, the event was constituted by the destruction of the public cemetery made by part of the population of the city of Salvador, Bahia in 1836. ${ }^{4}$ The action was made as a revolt against the end of the burials inside the catholic churches and can be understood as a reaction of the religious 
ARMITAGE, John. História do Brasil. 2a edition. São Paulo: Typographia Brazil de Rothschild \& Cia, 1914. p.200-201.

6

ARMITAGE, John. Loc. Cit.; AMARAL, Tancredo do A História de São Paulo ensinada pela biographia dos seus vultos mais notáveis. $2^{2}$ edition. Rio de Janeiro/São Paulo: Alves \& Cia. Editores, 1895. p.159-160; PINTO JÚNIOR, Dr. Joaquim Antônio. 0 Dr. João Baptista Badaró. Revista do Instituto Histórico e Geographico Brazileiro, Rio de Janeiro, tomo XXXIX, p. 343-344, 1876.

7

PINTO JÚNIOR, Dr. Joaquim Antônio. Loc. Cit.

8

O OBSERVADOR CONSTITUCIONAL. São Paulo, n.103, 22 november 1830, p.411 e n.104, de 26 november 1830. Biblioteca Nacional. Rio de Janeiro, Brasil. Available in Hemeroteca Digital Brasileira, Biblioteca Nacional, in the following link: http://memoria.bn.br/DocReader/ docreader.aspx?bib=814326ctpasta $=a n o \% 20$ 182 Etpesq $=$ Badar\%C3\%B3 Acessed in 06 feb. 2014. brotherhoods, who felt weakened with the end of the burials in their temples. More than that, another important reason behind the popular action was the fact that the construction and even the administration of the graveyard would be - unpreceded in Brazil - made by businessmen. It was unacceptable for the rioters that these types of people would take care of a subject still considered inside the holy and ecclesiastical sphere. It was, therefore, a protest insurrection in defense of the keeping of the traditional catholic funeral rites, much more than an opposition funeral.

As long as the protest that happened in Salvador did not had the characteristic of opposition or, more specifically, of liberal opposition, as the funerals analyzed by Fureix, less than that, they had not opened new funeral rites, the context which they occurred take us back to the period of the First Reign, marked by countless rebellions, great part of them of liberal meaning. And it is related to this turbulent period that a fast and superficial search got me to a case of a funeral that would faintly remember some analyzes that were made by Fureix. It was the burial of the journalist Libero Badaró, killed in 1830, in the province of São Paulo.

Coming from Italy to Brazil in 1826, Giovanni Batista Badaró was medic and settled up in São Paulo, he was the founder of the newspaper of liberal tendency called O Observador Constitucional in 1829. Despite being a moderate newspaper, it eventually ended criticizing the Conservative Party, mainly when it reported the News from the Revolution of 1830 in Paris - precisely the one studded by Emmanuel Fureix - and urged the Brazilians to follow the example of the French people, who had dethroned Carlos X. According to reports made by the British trader John Armitage, his voice echoed through many people in different Brazilian cities (as Rio de Janeiro, Salvador, Pernambuco and São Paulo), creating expectations that would stimulate the liberals through the use of journals ${ }^{5}$. Let us see more about the matter.

Encouraged by the news of the journal, students of the "Juridical Class" would take action to put lamps and organize bands that played music across the city of São Paulo, crossing the streets in procession, and even showing other demonstrations of happiness in defense of the fall of the French government who was considered tyrannical and unconstitutional. As it may be, the acts were viewed as crimes by the ombudsman of the province, Candido Ladislau Japiaçu, who had prosecuted some protesters, like young students. When making an opened campaign in his journal against the ombudsman, Libero Badaró would be victim of an ambush, being hit by a gunshot in a street near to his house (that time called Rua Nova de São José) ${ }^{6}$, in São Paulo at November $20^{\text {th }}, 1830$.

In the following period of 24 hours when he was mortally wounded, Badaro accused the ombudsman Japiaçu as mastermind of the crime and made possible to the police to arrest the shooter. He left a "political testament", pronouncing a phrase that was made famous as a defense symbol of the freedom of the press that said: "I die defending the freedom" or "A liberal dies, but liberty doesn't".7 The newspaper, O Observador Constitucional, would devote his edition of November $26^{\text {th }}$, 1830 to the passing of Badaró. For the newspaper, the case of his murder would have had immediate impact in São Paulo and, about 5 thousands of people would have attended to his burial that would have numbered more than 8 hundreds of torches. The funeral procession had occupied the entire distance between his house and the Chapel of the Third Order of Carmo, in a route of approximately 0.7 miles, in the present historic center of the capital. 
9

GOETA, Augusto. Libero Badaró: o sacrifício de um paladino da liberdade. São Paulo: Estabelecimento Gráfico E. Cupolo, 1944. Consultation made by eBook, eBooksBrasil. org. Available in the following link: http://www. ebooksbrasil.org/eLibris/badaro.html. Acessed in: 06 feb. 2015; PINTO JÚNIOR, Dr. Joaquim Antônio. Op. Cit., p.343-345. See the references indicated in the editions mentioned above from 0 Observador Constitucional, as the journal called O Republico. 0 REPUBLICO. n.20, 08 december 1830, p.102 e n.25, 25 december 1830, p.124. Biblioteca Nacional. Rio de Janeiro, Brasil. Available in: http://memoria.bn.br/DocReader/ docreader.aspx?bib $=332704$ \&tpasta $=a n o \% 20$ 183\&pesq = badar\%C3\%B3 and http:// memoria.bn.br/DocReader/DocReader.aspx?bib= 332704\& EagFis $=110 \&$ Pesq $=$ badar $\%$ C3\%B3 Acessed in: 06 feb. 2015.

10

AMARAL, Tancredo do. Op. Cit., p.59-160.
According to Augusto Goeta and Joaquim Antonio Pinto Junior, a testimony from the time had stated that in the burial of Badaró, the people of São Paulo would have made spontaneous and significant homages to the victim in an imposing funeral. Even the mentioned authors or some newspapers from the period connected to the exalted party declared that the coffin was held in the "arms" of his allies, from his house all the way to the church of Carmo. The number of people was such that, even without the coffin leaving the house, the procession was already in the church, located in the other half of the city, very far from there. The journals had implied that almost all the population of São Paulo was attending to the funeral of the "martyr of liberty" and that the burial had united rich and poor. That way, men from all classes (ecclesiastic, military, civil servants, traders, judges, lawyers and many other) would have followed, sorrowfully, the mournful procession, which could be felt in the faces of everyone a mixture of feelings that mutually fought each other: sometimes the mourn overcame, and sometimes the resentment against the responsible for that disaster. Yet months after the funeral, there were still compliments about the deceased. ${ }^{9}$

In that sense, the death of Badaro would have let the city inhabited by only nine thousands of people in the verge of insurrection and generated protests in different locations across the Brazil. The memory of such event would be so strong that one of his biographers, Tancredo do Amaral, would have stated that in his grave (that now is located inside the Consolação Cemetery) were recorded his last words in the defense of liberty. ${ }^{10}$ The interesting in this affirmation is that, if we analyze the image of Badaro's grave, which is now in the referred cemetery, we can't find the existence of the epitaph containing the last words proffered by Badaró, like we can see:

\author{
Alla mano del sicario \\ All'ingiuria del tempo \\ Gl'italiani riverenti alla gloria \\ Vendicano \\ In G. B. Libero Badaró \\ Il pensiero del sofo \\ Il cuore del medico e del cittadino \\ L'umanitá \\ [LOOSE TRANSLATION] \\ To the assassin's hand \\ The injury of time \\ The Italian reverence the glory \\ Revenge \\ That in G. B. Libero Badaró \\ The thinker of sofo \\ The heart of the medic and the citizen \\ The humanity
}




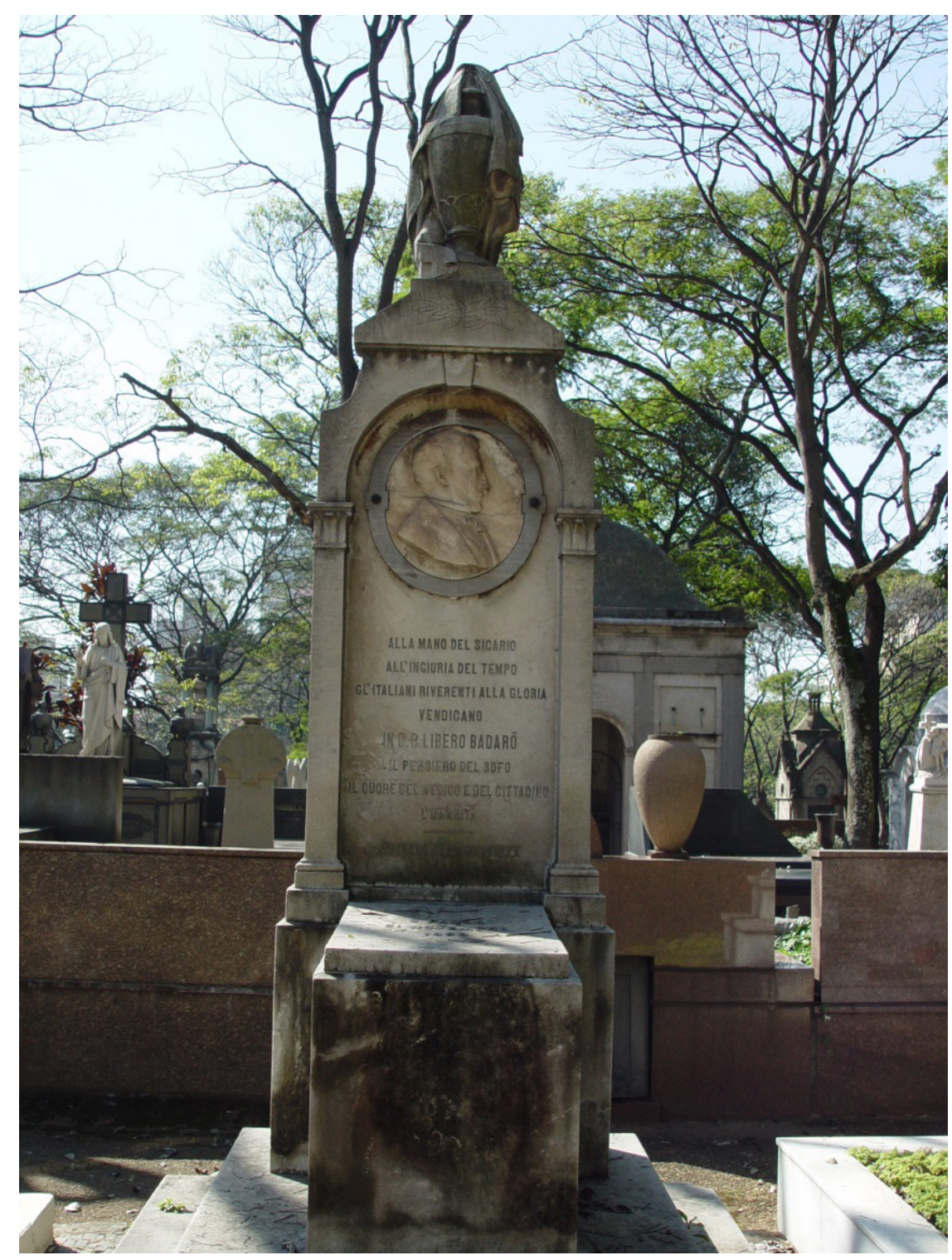

The grave of Libero Badaró in the Consolação Cemetery, located in São Paulo. Photography by: Glaucia Garcia

If we follow the references made by Augusto Goeta, this grave would have been built at the initiative of Italian citizens to honor the memory of his fellow countryman, with those words above carved on it. The piece was finished at 1889, when the relocation of Libero Badaró mortal remains was made from Church of Carmo to Consolação Cemetery at November $24^{\text {th }}$. In other words, just after the Proclamation of the Republic, in the week they honored another year of Badaró's death. This ceremony would have united about five thousands of people in São Paulo and there were numerous associations, freemasonic lodges, members of the provisional government and "compatriots of the martyr" involved in the event. Short time after,

11

GOETA, Augusto. Op. Cit.; AMARAL, Tancredo do. Op. Cit., p.160. the Municipal Council of São Paulo changed the name of the São José street, where Badaró lived, to honor his memory." While the objective of this article is not to engage further in this matter, it is really remarkable the impact that the ceremonies surrounding the death and funeral rites of Badaró exerted in the process of making his memory, even after a long time since the ritual.

This is just one example of what we can identify as a funeral rite, in Brazil, who had some elements alike to the "opposition burials" - if we 
12

To this matter, look for BASILE, Marcello. 0 Império em construção: projetos de Brasil e ação política na Corte regencial. 2004. 432f. Tese (Doutorado em História). Instituto de História, Universidade Federal do Rio de Janeiro, Rio de Janeiro, 2004; PEREIRA, Christiane Peres. A imparcialidade para doutrinar: os impressos de Joaquim José da Silva Maia no Brasil e em Portugal (1821-1830). 2013. 123f. Dissertação (Mestrado em História). Departamento de História, Universidade Federal Rural do Rio de Janeiro, Seropédica, 2013; and many other.

13

RIBEIRO, Gladys Sabina; PEREIRA, Vantuil. 0 Primeiro Reinado em revisão In: GRINBERG, Keila; SALLES, Ricardo (org.). O Brasil Imperial: 1808-1831. Volume I. Rio de Janeiro: Civilização Brasileira, 2009.

14

RIBEIRO, Gladys Sabina. A liberdade em construção: identidade nacional e conflitos antilusitanos no Primeiro Reinado. Rio de Janeiro: Relume-Dumará, 2002.

15

This would not be inconceivable in that context considering the existence of a liberal tendency of the Brazilian clergy in the years of 1820 and 1830. Cf. RODRIGUES, Claudia; OLIVEIRA, Anderson José Machado de. El anticlericalismo en el Brasil. In: DI STEFANO, Roberto; ZANCA José (compiladores). Pasiones anticlericales: um recorrido ibero-americano. Bernal: Universidad Nacional de Quilmes Editorial, 2013. p.193-202. 16 PINTO JÚNIOR, Dr. Joaquim Antônio. Op. Cit., p.343-345.

17

PINTO JÚNIOR, Dr. Joaquim Antônio. Loc. Cit. use Fureix words - and know that: there was a death/murder of a liberal, crowd in the streets, the atmosphere of riots and consternation, the carry of the coffin over the shoulders and the pronouncement of eulogies on the grave. The empowerment of the opposition the funeral would have would be leveled according to the environment in which the murder occurred; in other words, the existence of a liberal opposition against the abuses of a monarch. This situation would even contribute to the abdication of D. Pedro I from the throne, almost six months after Badaró's death, in 1831. ${ }^{12}$

This is how the First Reign - including the period of the Regency ${ }^{13}$ - appears as an interesting period to make a study of this nature. In the end, the years of 1830 and 1840 in Brazil were specially marked by different types of popular involvement, like political conflicts, rebellions, riots, uprisings and street protests ${ }^{14}$ that could be transformed as rituals of protest following the example of Badaró. The last thing to be done would be to deepen the analysis of the funeral rites that happened in the situation and ask ourselves to what extent these affairs would demonstrate the emergence of new rites during the funerals that happened in the first half of the nineteenth century in Brazil. This is a theme opened for future researches, to analyze the availability or not to think of a possible environment of "opposition funerals" in Brazil of the 1800.

Meanwhile, until these researches become true and bring results, I don't believe that we can make a direct association of the information presented here about the event of Libero Badaró's funeral - and possibly other events - and the French context studied by Emmanuel Fureix. The base to this matter is the identification of information about the reports of the participation of priests ${ }^{15}$ among the crowd during Badaró's funeral, and the fact that the dying man searched and received the final sacraments in his final moments. According to Joaquim Antônio Pinto Júnior, "At 11 AM o'clock of the 21st day the holy Viaticum was brought to him accompanied of a large staff composed by (with few exceptions) the entire faculty of that time"16. Like that, the author continues his argument, the dying man would have received the "sacrament and the consolations of the Christian church with great welcome, the most profound respect, with the venerations of a pure soul in the presence of the only and one God, in the holy conditions he had been educated... His words were full of humility..." ${ }^{17}$ Furthermore, in the journals of the period there are references about the realization of religious cults honoring the soul of Badaro months after the occurred, as a way of not to make silence about that crime. In this sense, it is needed to see to what extent the involved with the opposition burials during the first half of the nineteenth century - in my opinion this matter would also be valid in France - would share a conception of death and after life absent of the religious or clerical perceptions. Or, to what extent can the permanence of anticlerical tendencies imply the refuse of the religious ceremony? These perspectives could still function normally, although they could have experienced alterations during a period of major social and cultural changes, changes which ambivalences could certainly be found.

These elements would sign to a time in Brazil which the sacred would still be present in the rituals of the still prevalent Catholicism. A major example of this matter is that at the time of Badaró's death the burials would happen inside the catholic temples and the public cemeteries had not come to exist in the surroundings of São Paulo, to exemplify Père-Lachaise. In truth, not even a single Brazilian city would have these 
CYMBALISTA, Renato. Cidade dos vivos: arquitetura e atitudes perante a morte nos cemitérios paulistas. São Paulo: Annablume, 2002; PAGOTO, Amanda Aparecida. Do âmbito do sagrado ao cemitério público. São Paulo: IMESP, 2004.
VAN GENNEP, Arnold. Os ritos de passagem: estudo sistemático dos ritos da porta e da soleira, da hospitalidade, da adoção, gravidez e parto, nascimento, infância, puberdade, iniciação, ordenação, coroação, noivado, casamento, funerais, estações, etc. Petrópolis: Vozes, 2011. 20

To comprehend the new elements present in these funeral rites, see FUREIX, Emmanuel. Un rituel d'opposition sous la Restauration: les funérailles libérales à Paris (1820-1830). Genèses. Sciences sociales et histoire, Paris, n.46, p.77, mars 2002

21

Cf. FUREIX, Emmanuel. Rites protestataires et tensions démocratiques en France à l'âge romantique (1820 - 1848). Almanack, Guarulhos, n.09, p.07, abril de 2015.

To more details, see FUREIX, Emmanuel. La france de larmes. Deuils politiques à l'âge romantique (1814-1840). Paris: Champ Vallon, 2009. p.360-364. cemeteries. At São Paulo, where Badaró had been buried, this process would only occur in $1858^{18}$. That explains the fact that Badaró's corpse had been buried inside the Church of Carmo. In this sense, would be wrong to think that the event of Badaró's burial suggest a total similarity of Brazil and France. The very sense of the opposition rite in France cannot be automatically incorporated in a society who was still slaveholder, not capitalist, had a monarchy under the union of Church and Government, and at last, in Brazil, where the elements which made the first movements of democratic foundations arise in France, here were not present.

Such context differences, however, cannot make us forget that, even for the France, as Fureix identifies for the 1820's and 1830's, would likely to fit under still specific practices. His article analyzes a type of ritual who was not the most likely to occur during the predominantly catholic acts of that time in the face of death, the dead and the dying itself. To what extent those opposition funerals found by him could have completely broken with the visions about the afterlife that were commonly known? In what sense they could possess threat - or not - to the ecclesiastic catholic hegemony about death, during the French Restoration? The fact that the opposition funerals were inserted by the author as part of the protest rituals developed inside a public space reconfigured by the fall of the Empire and the imposition of a monarchy of representative basis that overcame the link of the conspiracies and the violence - just like the space destined to the institutionalized renew practices, as the census voting, parliament resolutions and petitions - already allow us to realize his specificities. Specificities that are connected to the fact that, although being traditional in their form, while being a rite of passage ${ }^{19}$, they would be funerals that invented modern and subtle ways of political participation in the urbanized and still pre-democratic areas of France. We can't forget the affirmation made by Fureix that the funeral rites as new means of takeover the public space as forms of protest were invented by the French Restoration, as a new gesture integrate to the modern repertory of collective action. ${ }^{20}$ This would show its characteristic as an exception.

About this matter, a question that catches my attention in Fureix article is that, on what extent the people which were present there were sharing that new type of funeral rite and the new beliefs about death and afterlife, taking into account that there was a significant number of people who joined as spectators, and that part of them were afraid of what they were seeing? How to distinguish? Maybe if Fureix could analyze the impact that the ceremonies caused into the defenders of the traditional habits. What does he suggests, in certain part of the article ${ }^{21}$, at page number four, when he mentions the scandal that these funeral rites were full of cries and songs which were sometimes seen as seditious?

This question about the punctual characteristic of the "opposition funerals" from the first half of the nineteenth century of France conduct me to think about a final point that I want to highlight in Fureix article: the fact that these burials cannot be mechanically mistaken by the reader as the emergence of a new funeral rite, the one called "civilian burial". Although the author had cited a ritual who was deliberately civilian among the opposition burials, where the presence of elements that would remember religion or the Church were explicitly refuted, and had mentioned the existence of two-thirds among the opposition funerals of the 1830's' ${ }^{22}$, the civilian funerals would be more characteristic of the second half of the 
About the civilian burials in France see: LALOUETTE, Jacqueline. Les enterrements civils dans les premières décennies de la Troisième République. Ethnologie française nouvelle serie, Paris, t.13, n.2, p.111-128, avril-juin 1983; AVNER, Ben-amos. Victor Hugo et les enterrements civils. Romantisme, Paris, n.119, p.35-45, 2003; Idem. Funerals, Politics and Memory in Modem France 1789-1996. Oxford: Oxford University Press, 2000.

24

A Portugal example. Cf. CATROGA, Fernando. 0 céu da memória: cemitério romântico e culto cívico dos mortos em Portugal (1756-1911). Coimbra: Livraria Minerva, 1999.

25

RODRIGUES, Cláudia. Nas fronteiras do além: a secularização da morte no Rio de Janeiro (séculos XVIII e XIX). Rio de Janeiro: Arquivo Nacional, 2005.

26

According to Giacomo Martina, the mainly concrete applications of the Liberal principles in relation to religious matter can be summarized in the following topics: a purely human and conventional origin of society and authority; the political unity based upon the identity of political interests; end of the concept of "religion of State" and affirmation of the complete freedom of conscience; civil laws not guided anymore by the canonical organization; many activities, until then exerted predominantly by the Church, had been claimed by the Government (such as the administration of the cemeteries); end of the typical immunities of the Ancien Régime. In face of the advance of the Liberal world, the Holy See would undertake a constant fight against the affirmation of the separatist principle during the nineteenth century, especially during the second half. Cf. MARTINA, Giacomo. História da lgreja de Lutero aos nossos dias. São Paulo: Edições Loyola, 1996. p.49-81, t.Ill.

27

CATROGA, Fernando. Op. Cit., p.139-170.

28

Ibidem, p.150-151.

29

CATROGA, Fernando. Loc. Cit.

30

Ibidem, p.157.

31

To further clarification of his work and political action, see VIEIRA, David Gueiros. 0 protestantismo, a maçonaria e a questão religiosa no Brasil. $2^{a}$ edition. Brasilia: Editora da UnB, 1980. p.95-112. 32

Ibidem, p.52. The justification for this choice was the belief that the material progress (scientific and technologic) and the political progress (the subject's freedom) came from the protestant countries. It was indeed considered by him a necessity for the progress of the country. Cf. VIEIRA, David Gueiros. Liberalismo, masonería y protestantismo en Brasil, siglo XIX. In: BASTIAN, Jean-Pierre (compilador). Protestantes, liberais y francmasones: sociedades de ideas y modernidad en América Latina, siglo XIX. México: Fondo de Cultura Económica, 1990. p.50-51 e MENDONÇA, Antônio Gouvêa. La cuestión religiosa y la incursión del protestantismo en Brasil durante el siglo XIX: reflexiones e hipótesis. In: BASTIAN, Jean-Pierre (compilador). Op. Cit., p.79. nineteenth century, mainly after 1870 . In this occasion, even in France ${ }^{23}$ as the remaining countries of the western Europe ${ }^{24}$ and in the Americas, Brazil included ${ }^{25}$, there would be developed new funeral rites in the international process of laicization and questioning about the ecclesiastic hegemony in the catholic monarchies, expressed in some of the liberal movements, positivists, republicans, protestants, freemasons, and many others, which defended the stormy proposition of religious freedom that, in some cases, took the form of secessionist or secularized way of searching for autonomy of the civilian power front the ecclesiastic power ${ }^{26}$.

Adopted in the context of the diffusion of the anticlericalism of the second half of nineteenth century, the civilian burial was defended by the supporters of the elimination of the ecclesiastic control on the funeral rites. In these types of funerals, there would be absent the rituals of the Catholic Church and the priests. This proposition was made by the defenders of the free thinking and by the critics of the ecclesiastic power on the society and its behavior. ${ }^{27}$ According to Fernando Catroga, they were directly related and dependents upon the "level of secularization of society, acknowledgement of religious freedom and acceptance of cemeteries as places of free access."; hence the "articulation of its propagation with the struggles of the separation of Church and Government and the secularization of the necropolises." ${ }^{\text {28 }}$ Struggles that, in Portugal, lasted since the end of the decade of 1860 and ended only with the laws of laicization of the Republic, in 1910-191129. In the aspects of the ritual, the civilian burials were organized outside the clerical and religious control:

\begin{abstract}
(...) in addition to the Family, frequently it was the coworkers or the associations that the deceased attended to (political clubs, professional associations, cultural associations, freemasonry organization, etc.) that would take care of the active part of announcing the death and organize the funeral (the mourning, order of the procession, speeches on the grave). It will be said that these characteristics could be found in the catholic burials. But, in the civilian option, the absence of the priest and the religious symbols would give them an image of profanity. And that existed a careful surveillance about the presence of symbols that could misrepresent its meaning, proves it this occurrence: when in a civilian funeral for a child (held in Lisbon, March 1882), there happened to appear 'a cross suspended high and immediately was given the order to the owner to retract such symbol'. This example reveal the differences between the religious ceremony and the civilian ceremony; in the later, the priest bearer of the Blessed Sacrament and the holy oils in the moment of mourning, the cross, the children choir in front of the procession and the ringing of bells were all missing. ${ }^{30}$
\end{abstract}

Regarding Brazil, it was just in the 1870's that I could identify one of the first funerals with the presence of these elements of civilian nature and not of merely opposition. It was the burial of Tavares Bastos, an intellectual and politician who had an outstanding performance in the great debates of the second half of the nineteenth century in Brazil ${ }^{31}$. Among the libertarian causes he took part, the defense of Protestantism was one of the most active during his political and parliamentary activities. He was part of the intellectual and liberal group of politicians which were interested in the promotion of the "economic progress" of Brazil, and they shared the opinion that associated Protestantism and progress believing that the solution to the economic and developmental problems of Brazil was in the massive importation of protestant immigrants from the Germanic states, England and United States ${ }^{32}$. 
33

MENDONÇA, Antônio Gouvêa. Op. Cit., p.95.

34

0 GLOBO. Rio de Janeiro, 8th year, n.121, 2 may 1876, p.1. Biblioteca Nacional. Rio de Janeiro, Brasil.

35

0 GLOBO. Loc. Cit. One of the first public cemeteries around the city of Rio de Janeiro, in 1851 , made by the occasion of the prohibition of the burials inside or within the churches. Cf. RODRIGUES, Cláudia. Lugares dos mortos na cidade dos vivos: tradições e transformações fúnebres no Rio de Janeiro. Rio de Janeiro: Secretaria Municipal de Cultura/Divisão de Editoração, 1997

36

O GLOBO. Rio de Janeiro, 8th year, n.121, 2 may 1876, p.1. Biblioteca Nacional. Rio de Janeiro, Brasil.
An United States admirer, a lover of the American way and progress, Tavares Bastos sponsored the British, North American and German immigrations to Brazil and fought other battles, examples are where he purposed the opening of the Amazon River to international traffic, free trade, liberalization of the trade laws, and many others. In relation to the difficulties that the immigrants could find in Brazil, due to the problems of the inexistence of a civil code that acknowledges the births and marriages "non-Catholics" and due to the Church jurisdiction over the majority of the Brazilian public cemeteries, he defended the liberalization of the Brazilian legislation. He believed that the Brazilian laws needed to be adapted to the manners and behaviors of the "non-Catholic" immigrants. From this point the necessity, as an example, of the implementation of the legal marriage (in order to make the children have the legitimacy and right to the transmission of patrimony), secularization of cemeteries and freedom of religion ${ }^{33}$.

Happened in the city of Rio de Janeiro, May of 1876, his funeral was stated by the journal 0 Globo as "a solemnity without antecedents in the annals of our society". The reading of the post from May 2nd of that year allows us to identify the report of the ritual that had followed the situation.

Had landed in the navy arsenal, the coffin of Tavares Bastos was deposited in the chapel of the same arsenal, were the procession would have started at evening. At three o'clock, the members of the journal waited at the doors of their establishment for all the people who would follow them and their "distinct colleagues" of the journal Gazeta de Noticias in the "appropriate tribute to the corpse of the eminent citizen". From there, they left together to the navy arsenal where they formed the funeral procession. The journal invited "the population in general, without distinction of either parties or categories, searching to raise the popular manifestation and democracy to the level of the noble feeling that inspire[d]"34.

The editors told that the clothes that would be used were either overcoat or a black suit. In the navy arsenal, the coffin were put in the funeral carriage, having four cords hanged up in each side which were conducted by the person that the family or the person that represented it had given that honor. The procession walked like a parade, with the guests walking on foot. The route followed this way: Primeiro de Março Street, Ouvidor Street, São Francisco de Paula Square, Teatro Street, Constituição Square and Visconde de Rio Branco Street until the intercession with Lavradio Street, where the cars of the invited people were parked, and from there, they would go to the São João Batista cemetery ${ }^{35}$.

After this report, the editorial made an eulogistic statement about the "great role" of Tavares Bastos, whose life was completely focused in study, work and to the "patient and enlightened" investigation of the way that would, in the future, provide the "greatness and glory that all the people" of Brazil longed for. His privileged intelligence would have been opened to all the bold ideals, his gracious soul to all the noble feelings and his dedication devoted to the "public good". Without any type of engage in religious matter, the text would follow its course talking about the political and intellectual image of the deceased. ${ }^{36}$

In the end, it was made a funeral eulogy by the authorship of Dr. Ferreira de Menezes; the content was referring to the death of Tavares Bastos and his corpse, emphasizing his political and parliamentary actions, his conflict and his patriotism. One of the parts of the eulogy referred to his death without the use of the traditional soteriological or eschatologi- 
cal elements, fitting his death to a process more biological and exalting the civilian and patriotic virtues of the dead, as we can see in the fragment: "There comes the dead body of Tavares Bastos, the standard-bearer of the democratic ideals of his time! Here comes the cold head that never got tired of thinking and calculating the future of his country. Here comes motionless the heart that at every beat marked a though about love to his land!" ${ }^{17}$

The journal had still listed the corporations, institutes and education establishments that expressed representation during the funeral ceremony, in addition to the people that had joined to that "patriotic homage". Were present: the press, through the different editorial offices; the Grande Oriente Unido, through a commission composed by a lot of people and Quintino Bocaiúva; the Associação Comercial, through a commission composed by two Executive Officers; the freemasonry lodge Saldanha Marinho which the deceased was an Instructor, by a commission composed of many people; the Instituto Farmaceutico, through a commission composed by distinct gentleman; the Ateneu Acadêmico, composed by some gentleman. Other institutions that, according to $O$ Globo, were there through commissions are: the Ensaios Acadêmicos, the Ensaios Literários, the Escola Politécnica, the Escola de Medicina, the Clube Politécnico, the Sociedade Alta Literário, the Retiro Literário, the Grêmio Literário, the Liga Operária, the Colégio Vitório, the Internato and the Externato Aquino. ${ }^{38}$ Were present into the procession some illustrious people, who deserved the notice of the Family, such as: the minister of Navy and the counselor Saldanha Marinho. Among them, the journal mentioned the presence of the vicar of Sant'Anna; it just doesn't make it clear how he attended, as a guest or officiant. In the escort with the car to the cemetery were present the minister of Agriculture and the minister of Navy, and a lot of civil servants too. No religious brotherhood was mentioned.

In the cemetery, several speeches were made and the journal had listed the names and the titles of the speakers. Among the offered wreathes, the journal noted the ones sent by the editorial offices of Reforma, Gazeta de Notícias, Mosquito, and Revista llustrada; sent from Retiro Literário Português, Grêmio Literário, freemasonry lodge Saldanha Marinho and in addition to the ones who were put in the coffin by the editorial office and the workers of 0 Globo. Many houses raised the national flag in half-mast "as a demonstration of mourning". When passing just outside the central station of the company "Botanical Garden Rail Road", a large number of employees were in front of the company and the American flag was hoisted three times as a compliment to the dead. The journal also mentioned the presence of foreign people, consulate representatives and foreign ships that, in the harbor, had their flags at half-mast ${ }^{39}$.

Front of the grave, the senator F. Otaviano tried to make a speech in memory of his friend and coreligionist, but the commotion kept him from doing it and so the text was sent to the journal to be transcript for the edition of the following day. The parliamentarian made homage to "the citizen that had ennobled his homeland with good services and virtues". Talked about the acts the dead had made to promote improvements in the country. Commented his works, said that he was there to say his "everlasting goodbye" and deposit reminiscence (flower) over his grave. Many other discourses sent to the editorial office of $O$ Globo were transcript, apart from several poems that for further days appeared in the pages of the journal. In these and in the poems were highlighted the patriotic 
O Apóstolo was a catholic journal that was impressed in Rio de Janeiro between 1866 and 1901. Represented an official Chanel of the Rio de Janeiro diocese and had as targets propagate and defend the interests of the bishopric. For further analysis of this journal see GOMES, Francisco Jose Silva. Le projet de néo-chrétienté dans le Diocèse de Rio de Janeiro de 1869 à 1915. 1991. 3 vols. Thèse de doctorat. Université de Toulouse Le Mirail, Toulouse, p.349-353 and ABREU, Martha. O Império do Divino: festas religiosas e cultura popular no Rio de Janeiro, 1830-1900. Rio de Janeiro: Nova Fronteira; São Paulo: FAPESP, 1999. p.312-315.

42

The action of Holy See, especially during the pontificate of Pio IX, seeking to "reunite around it bishops, priests and believers, to further resists the incipient process of secularization of society", conformed what it conventionally was to be called ultramontanism, as one of the mainly characteristics of the Church during the nineteenth century. Appointing the tendency of Catholicism during this century for seeking the fortification of the papacy, even in the Government as in the mastership of the Church, the Catholics should see the Pope as the mainly leader and mediator between society and the spirit world, in addition the laic and the religious should be submissive to the initiatives and guidance of the Holy See. Cf. MARTINA, Giacomo. Op. Cit., p.117, t.III. SANTOS, Patricia Teixeira. Ultramontanismo. In: SILVA, Francisco Carlos Teixeira da; MEDEIROS, Sabrina Evangelista; VIANNA, Alexander Martins (orgs). Dicionário crítico do pensamento da direita:idéias, instituições e personagens. Rio de Janeiro: FAPERJ/ Mauad, 2000. p.444. According to David Gueiros, the "ultramontanism" was a term used since eleventh century to describe the Christians that sought Roman leadership ("the other side of the mountain"), or that defended the point of view of the Pope, or provided support to the politics of the same. In the nineteenth century, it reappeared, representing a number of concepts and attitudes of the conservatory side of the Catholic Church and its reaction to what it considered excessive of the French Revolution. Cf. VIEIRA, David Gueiros. 0 protestantismo, a maçonaria e a questão religiosa..., Op. Cit., p.32.

43

EDITORIAL: "Um enterramento civil". In: 0 Apóstolo. Rio de Janeiro, ano XI, n.50, 05 de maio de 1876. Biblioteca Nacional. Rio de Janeiro, Brasil.

44

EDITORIAL: "Um enterramento civil". Loc. Cit. 45

EDITORIAL: "Um enterramento civil". Loc. Cit. Emphasis in the original.

46

EDITORIAL: "Um enterramento civil". Loc. Cit. Emphasis in the original.

47

O APÓSTOLO. Rio de Janeiro, year IV, n.19, 09 may 1869. Biblioteca Nacional. Rio de Janeiro, Brasil. Seção "Diocese do Rio de Janeiro - circular".

48

CATROGA, Fernando. Op. Cit., p.157. compliments to the deceased, in which there were almost no mention to Christian eschatology. ${ }^{40}$

The unexpected of the entire ritual can be proved by the criticism made by the ecclesiastic hierarchy about the ceremony, three days after the funeral, through the catholic ultramontane journal, the so called 0 Apóstolo. ${ }^{41}$ The paper pronounced itself against the events and with the so waited invective - something that kept happening since the ending of the 1860 's, in the conjuncture of the struggle between ultramontanism ${ }^{42}$ and defenders of the liberal ideals. Entitled as "A civil burial", the edition of May, 5th of 1876 lamented that the funeral of the liberal Tavares Bastos ${ }^{43}$. The editors said that it was "extremely ridiculous" the utilization of an act "so solemn" between the Catholics, with the "transportation of a dead body to the cemetery, to perform a pagan solemnity" which disgusted the feelings of "the most part of the Court" that watched it "more for admiration to the audacity of the promoters of the feast than for any other possible feeling"44. To the Catholic paper, it was not its behalf to fight the memory of that that was knew as "sectarian of the liberal doctrine". Quite the opposite, it acknowledged its intelligence, independent nature and honor. What it criticized was "those who, searching since long ago to reproduce in Brazil the burial system adopted by the sectarians of Darwin, Hegel and the like, realized that they should use it among us in the occasion of the funeral procession of the mortal remains of Dr. Tavares Bastos".45

All this explicit astonishment contained in the column of the Catholic journal was done because of the use of the corpse of Tavares Bastos as an excuse for a burial that banned "any symbol of the religion which he belonged to; and lived, even if freely, but with no blaspheme against it" 46 . For 0 Apóstolo, the journal 0 Globo had contributed for the whole "scandal", when it impressed in its column that "insulting" headline at May 3rd. It is evident the nonconformity of the Catholic journal against a funeral where, in addition to not having the presence of the clergy as officiant, it didn't had shown the respect that the Church believed it should have had while in the cemetery.

The practice of lay people to pronounce speeches over the graves, taking up the place that the Church believed to be of the Clergy was something that, for some time, were being opposed during that second half of the eighteenth century. An example is the document that the Vicar General of the bishoprics of Rio de Janeiro, Monsignor Felix Maria de Freitas Albuquerque, had sent to the priests in May 7, 1869 condemning the practice of pronouncing funeral discourses at the Churches during the requiem mass of the seventh day, held in that diocese. According to the Vicar General, that "abusive practice of secular people of pronouncing funeral discourses" was dangerous for causing "serious scandal" to many believers and because of the perturbation it caused to divine services, constituting of "clear contempt of the Church laws that only in exceptional cases were let funeral prayers and even this was made with the permission of the Ordinary" ${ }^{47}$.

As stated by Fureix, Fernando Catroga said that the civilian funerals represented a reply to the great ostentation of the religious funerals ${ }^{48}$ that relied on many light, prayers, bells, and songs aside from the presence of the religious brotherhood which made the ceremony rich. On the other hand to this ostentation of the ecclesiastic burials, the civilian burials were far cheaper. Usually they were adopted by anticlerical, socialists and 
49

Ibidem, p.159.

SILVA, Antônio Moraes e. Diccionário da língua portuguesa recopilado por vocabulários impressos até agora, e nesta segunda edição novamente emendado, e muito accrescentado. Lisboa: Typ. Lacerdina, 1813. p.438.

SODRÉ, Nelson Werneck. História da imprensa no Brasil. $4^{a}$ edição. Rio de Janeiro: Mauad, 1999. Sobre 0 Globo, ver p.195, p.223-224, p.252; sobre A Reforma, ver p.202 e p.211-212.

republicans. The author presents the steps followed during the ceremony in this type of funeral.

General rule, after the funeral, the coffin left the house of the deceased (or the head office of a political or cultural association) to the cemetery, following an itinerary previously set; in the front was the coffin without any crosses, usually it was covered by a black canopy or a flag from the society which the deceased was a member; In the flank, walked the relatives, the coworkers and the coreligionists, frequently there were present the deputations of socio-professional groups, faculty associations, republican parties or socialists with their flags; In the back were the anonymous; Surprisingly, there still was the participation of bands, with the intention to, in the absence of the ringing bells, spread the ceremony. One or more speakers ended the session making the eulogy to the deceased. And, in the end, in some ceremonies, were made some cheers.

In synthesis, just like France, the ritual had fundamentally new elements, not the presence of the speaker (in the catholic burials of some notables speeches were made too), but above everything else, the presence of flags (red-colored), the cheers, the throwing of clods of earth over the coffin, the carry of Globe Amaranth. ${ }^{49}$

When we analyze this description made by Catroga about the elements that were present in the civilian burial ceremonies, the first note we can make is that the funeral of Tavares Bastos contemplated by 0 Globo had many similar points: the previously set route, the presence of socioprofessional and faculty deputations - not having any mention about the presence of religious brotherhoods, traditionally found during the funeral rites - and, in lastly, the mention of Globe Amaranth, who were purple flowers that would discolor even when dried ${ }^{50}$. The speeches made over the resting place of Tavares Bastos mentioned this flower when it was said that they left reminiscence over the deceased's grave. When they used a flower that would not discolor even after dried and named it reminiscence, it meant the memory of the dead that it could not be left to die. The habit of using flowers during the funeral was other practice strongly condemned by the catholic ecclesiastical hierarchy of that time. It was a habit adopted by the Greeks and the Romans in the cult of the cemeteries that the newly born Catholic Church associated to pagan rites because it was related to idolater's symbols. So much that since the second century the set of crowns over the grave of Romans was condemned by members of the ecclesiastic hierarchy.

About the critics made by the Catholic ecclesiastical hierarchy of Rio de Janeiro against the funeral of Tavares Bastos, I don't have any clues until this moment of any other ceremony following that format in the decade of 1870. It is possible that others happened, especially of those who criticized the current order. This indicates that, in the city of Rio de Janeiro, during that time that happened to be a practice secluded of the usual. The very fact that $O$ Globo featured the occurred demonstrates the unusual aspect of that ceremony. Even though the highlighted feature made by this journal were not free from interest, after all, it was a journal of Liberal and republican tendencies, headed during that time by Quintino Bocaiúva and that, united with the republican militant $A$ Reforma was in the front of the expressive obituary notices of the press in honor of Tavares Bastos from Alagoas ${ }^{51}$.

The funeral of Tavares Bastos, as so, looks like it was the exception that confirms the rule of the still existent predominance of the funerals marked by the clergy influence in the city of Rio de Janeiro. Although, it 
To further detais, see RODRIGUES, Claudia. Nas fronteiras do além..., Op. Cit., mainly the chapters 4,5 e 6.

53

MARCELINO, Douglas Attila. O corpo da Nova República: funerais de presidentes e memória de Tancredo Neves. 2011. 422f. Tese (Doutorado em História Social). Instituto de História, Universidade Federal do Rio de Janeiro, Rio de Janeiro, 2011

54

Idem. Os funerais como liturgias cívicas: notas sobre um campo de pesquisas. Revista Brasileira de História, São Paulo, v.31, n.61, p.125-144, 2011 Idem. Liturgias cívicas e ritualização do poder: funerais de presidentes e memória de Tancredo Neves. In: SIMPÓSIO NACIONAL DE HISTÓRIA - ANPUH, 26., 2011, São Paulo. Anais do XXVI Simpósio Nacional de História - ANPUH. Available in: http://www.snh2011.anpuh.org/resources/ anais/14/1300631367_ARQUIVO_TextodaAnpuh. pdf. Acessed in: 19 feb. 2015. Idem. Funerais de consagração cívica e escrita da História no Brasil (1870-1930). In: SEMINÁRIO BRASILIERO DE HISTÓRIA DA HISTORIOGRAFIA, 6., 2012 , Ouro Preto. RANGEL, Marcelo de Mello; PEREIRA, Mateus Henrique Fari; ARAUJO, Valdei Lopes de (orgs). Caderno de resumos \& Anais do $6^{\circ}$ Seminário Brasileiro de História da Historiografia - 0 giro-linguístico e a historiografia: balanço e perspectivas. Ouro Preto: EdUFOP, 2012

55

GONÇALVES, João Felipe. Enterrando Rui Barbosa: um Estudo de Caso da Construção Fúnebre de Heróis Nacionais na Primeira República. Estudos Históricos, Rio de Janeiro, v.14, n.25, p.135-161, 2000.

56

Courtesan political tendency, defender of the Dom Pedro I government, even in the press as in the parliament until 1831, in the context of the street riots during the First Reign. Defenders of the Constitution granted in 1824 and the Moderating Power sought for a medium between what was considered despotism government and anarchy of the masses. Cf. PEREIRA, Christiane Peres. Op. Cit., p.11, p.114-115 e BASILE,

Marcello. Governo, nação e soberania no Primeiro Reinado: a imprensa áulica do Rio de Janeiro. In: CARVALHO, José Murilo de; PEREIRA, Miriam H.; RIBEIRO, Gladys Sabina; VAZ, Maria J. (orgs.). Linguagens e fronteiras do poder. Rio de Janeiro: FGV, 2011. p.173.

57

0 VERDADEIRO PATRIOTA. Maranhão, n.39, 08 march 1831. Apud. PEREIRA, Christiane Peres. Op. Cit., p.111.

58

0 NOVO CENSOR. Rio de Janeiro, n.6, 09 de march de 1831. Apud. PEREIRA, Christiane Peres. Op. Cit., p.112.

59

0 VERDADEIRO PATRIOTA. Maranhão, n.39, 08 de march de 1831. Apud. PEREIRA, Christiane Peres. Op. Cit., p.111. was sufficiently announcer that that control was beginning to be challenged somehow during the context of the Imperial Crisis. We should not ignore the quantity and variety of the associations and institutes that escorted the procession. And it was because of this that the ecclesiastic hierarchy thrashed so much against those practices. After all, in the conjecture of that time, experiencing criticism and threats by all sides, any trace of attitudes that could pervert its secular teachings about death and the dying should be bluntly assaulted and refused ${ }^{52}$.

There is nothing yet in the Brazilian historiography about death such as a specific area of research about the civilian burials during the Empire, as it exists about the traditional catholic funeral themes - be on the CoIonial period or during the Imperial period - marked by the clerical influence or even about the study of the construction of the public cemeteries around the cities during the middle of the nineteenth century. After focusing his analysis about the civilian funerals made during the occasion of the death of Tancredo Neves ${ }^{53}$, Douglas Átila Marcelino is recently covering the theme of the period between 1870 and $1930^{54}$, but we still lack the publication of articles with deeper understanding about the rites developed during the Imperial period. Other historians are studying the civilian funerals during the First Republic of Brazil, such as João Felipe Gonçalves and the funerals of Rui Barbosa in 1923 and other intellectuals and politicians in the first decades of the twentieth century. ${ }^{55}$

If references about the occurrence of civilian burials during the second half of the twentieth century in Brazil appear to be exceptional, I have yet to find references about the first half of the century in Brazil as Fureix found about Paris in the decade between 1820 and 1830 (even if these had been very specific). For this period, the evidences point toward the existence of funeral rites that present similarity to the "opposition funerals". And, as I mentioned before, the period of the First Reign, marked by the eruption of countless revolts certainly was subject to events of this nature. But this is a theme that is still opened to those interested in a specific investigation. Besides the case of the cited above Libero Badaró, other events must have existed, some with changes in their meaning.

An example is the one cited by Christiane Pereira about the funeral of the sycophant ${ }^{56}$ Joaquim José Silva Maia that happened in Rio de Janeiro, 1831, months after Badaró's funeral. Albeit not being an opposition funeral, it was a ceremony that contained actions of revolt and protest made by the exalted Liberals that intersected the procession in the direction of the Church that the funeral was moving to, criticizing the dead and his conservative stance in life. Different of Badaró's stance, Silva Maia was the founder of a journal of conservative tendency - the so called $O$ Verdadeiro Patriota - that would narrate the burial of its founder as a "dishonored scene to the Brazilian character!"57 The dishonored scene happened when the funeral was going to the church of the monastery of Santo Antônio and an exalted party, objector to the conservative stance of Silva Maia had insulted the people who wanted to lift the coffin - probably to carry it by hands - firing rockets and fireworks from China and shouting "indecent words" 58 . Considering the act as an infamy and "indiganity" [sic] O Verdadeiro Patriota said that some of the guests for the burial were forced to go out of the monastery with staves to resist against any insults that the rebels could make upon them. ${ }^{59}$ The reason behind the conflict was in the enemies of the dead to demonstrate their revolt against the 
60

PEREIRA, Christiane. Op. Cit., p.115. political stance of Silva Maia aligned to the "despotic" government of Dom Pedro I, when he defended the Constitution granted in 1824 and he having a discourse marked by the principles of order and tranquility typical of a conservative project ${ }^{60}$.

Beyond this example, other possible way of investigation of the relation between funerals, opposition and protest in the Empire of Brazil would be the study of the impact that the death of Dom Pedro I in 1834 between the Republican and Liberal critics that who were engaged in the process of his Abdication. Or the study of the rites connected to the burials of the dead during the Imperial revolts; among several possible studies.

It is because all of these reasons that I commend the merits of the study made by Fureix, which, among other aspects, it is the one that honor us with a purpose that just show us how much our studies about the attitudes in the face of death and political life in the nineteenth century still present a significant gap. We lack approaches that, being inspired in his work, seek to direct the gaze upon the relationship between funeral culture and power in the analysis of the political environment of death and the act of dying in the activities of more contesting nature during the Empire of Brazil, with the goal to identify its multiple dimensions.

Translated by Arthur Baltazar
Recebido para publicação em 22 de fevereiro de 2015.

Aprovado em 28 de fevereiro de 2015. 